\title{
The Contribution of Sports, Physical Education and Recreational Indices in Promoting Health and Peace among the Youth in Nigeria
}

\author{
Joseph Olayinka Awoyinfa, Oladipo Simeon Adebayo \\ University of Lagos, Akoka-Lagos, Nigeria
}

\begin{abstract}
The study investigated the contribution of sports, physical education and recreational indices in promoting health and peace in Nigeria. The study was sought to determine whether participation in sports will address the issues of conflicts, disputes and war in Nigerian society. This is because of the current escalation of religion, ethnic and cultural conflicts which are having devastating and profound impact on the peace, co-existence and the unity of Nigeria. The study focused was Lagos State. While the study adopted the descriptive research design, the participants consisted of 200 sports administrators, coaches, athletes and spectators randomly selected from 5 public sports centres and 5 private sports centres in Lagos State. The instrument used for data collection was questionnaire while the data collected were analyzed using chi-square statistics. Based on the findings of the study, it was concluded that active participation in sports with human development through sports and education, creates a way of life based on the joy of effort, educational value of good example and respect for universal fundamental ethnical principles and peaceful rivalry. It was recommended among others, that: adequate sporting facilities and equipment should be provided in schools and public recreational centres and should be made available, accessible and affordable to all, government should encourage sporting activities, sports seminars, sports conferences and sports workshops among all youths across the Nation and government should encourage competitive sports among the youth across the country in order to keep their mind off violence.
\end{abstract}

\section{Introduction}

In recent time across the globe, the world has been experiencing conflicts, dispute, political unrest, civil disobedience and war. The escalation of religious, ethnics and cultural conflicts is having a profound impact on generations after generations. Collectively recreational sports and physical education has been discovered as a powerful catalyst for promoting peace, Healthy living, freedom and cooperation among sports consumers if properly managed and maximized. All wars since the beginning of human history have been in the essence of struggles among brothers. Considering the history of man right from age of civilization to the modern era researches have shown that governments, institutions and religious bodies have not failed in using sports in their attempt to find lasting solutions to the problems which tend to cause war, Such efforts can be seen in an attempts made by organizations like NASM, NAPHERSD, SPAN, NUGA, WAGA to bring peace to the country Nigeria through organization and administration of sports programmes [1]. However, despite the political and religious crisis in Nigeria since 1994- till date, sports has remained an exciting unifying force that still keeps, the country together. The 2012 National Sports festival tagged Eko Sports festival attest to this that, the influence of Sports, physical education and recreation values transcends Political, Tribal and Religious differences. Sports take place in an atmosphere devoid of rancor nepotism and rivalry. Perhaps, the question now is what will our society, and Educational institutions looks like? all over the universe today without sports and Physical Education. There are many situations that globally promote war. These are ideological, Political and Economic forces which pull countries, states, town even villages apart, but sport, physical education and recreational values have been identified as a unifying force that bring States, Towns and Countries together irrespective of Language, Tribe and Cultural differences [2].

Currently, with the co-ordination and healthy development of Sports, through grassroots sports development in Nigeria today, it has led to the promotion and involvement of youth in active competition through sports and this make the youth to be more responsible and put their minds off violence. When one ponders what would happen have to Nigeria without sports and recreational activities, what will really come to mind is a state of anarchy and rancor. Imagine what the State of the Nation will be without Nigeria Premier Leagues, NUGA, WAUG and other National and international games, like the just concluded AFCON (2015) held at Equatorial Guinea despite the fact that Nigeria couldn't, qualified for the event, the focus of the entire youth of the nation was on the event from start to finish, Coupled with regular interhouse sports competitions that occupies the youths and Principal's Cup Competitions. Furthermore, what will the television programme be without sports news, as well as the state of any business without marketing through sports, sport advertisements and sport sponsorships which brings to light various organizations. How much tension will be recorded in our educational institutions without sports and recreations which arrest and usurp potential energies 
in the youths? Sports programmes and related sports activities are regular discussion in most states of the country. Sports, physical activities and recreation reduce idleness and encourage the enjoyment and entertainment on the part of spectators. Participants are able to make more contacts, more friends and even more money. Sports help them have the tendency to broaden, spread, diversify and helps to assume a greater role in the general security system of any Nation if properly maximized mostly in Nigeria to reduce the tension and anxiety caused by the book Haram insurgency in the North and youth militants in the Niger Delta region. However, over the years this practice has become extremely violent leading to senseless loss of lives, destruction of property, rape and killings of human beings. Youths should engage themselves in recreational activities to curb substance abuse, cultism, killings, and any act of hooliganism [3].

Globally, sport is considered as a creator of beauty and as an instrument of ethical values that brings about peace, unity and understanding among people of all races, during sports participation which wholly the result of social invention and social heritage. Sports are highly significant in national development through leisure and recreation as it enhance a high degree of productivity and healthful living [4], health as the quality of life which enable man live most and serve best. Sports are one of the greatest endeavors in human experience. It is a celebration of physical excellence which involves the ability to sustain and maintain ones physical health in such a situation that one would be able to walk, run, think and move the parts of the body as may be demanded. It is a medium through which competition, friendship, tolerance, unity, discipline, endurance and diplomacy are promoted. Sports as a social event is a civilizing and socializing process of gathering men and women of good will who came together to take part in athletics and sporting events for the purpose of physical, mental, social and political development . Sport is a social agent which brings people of different ages and religious background together as either producer or consumers (players or spectators). It is a social link among nations of the world. To the whole world, sport has become an effective instrument of international politics and one of the easiest ways of promoting the image of a nation. [5]

\section{Meaning of Sport}

Sport is all forms of usually competitive physical activity which, through casual or organised participation, aim to use, maintain or improve physical ability and skills while providing entertainment to participants, and in some cases, spectators. Sport is generally recognised as activities which are based in physical athleticism or physical dexterity, with the largest major competitions such as the Olympic Games admitting only sports meeting this definition. Perhaps even more diverse than the meaning of 'development' is the variety of meanings that have been given to 'sport' in the research reviewed. The RFP prepared by the SDP IWG/Right To Play defines sport as: "all forms of physical activity that contribute to physical fitness, mental well-being and social interaction, such as play, recreation, organized or competitive sport, and indigenous sports and games. "Sport means all forms of physical activity which, through casual or organized participation, aim at expressing or improving physical fitness and mental well-being, forming relationships or obtaining results in competitions at all levels [6].

\section{Contributions of Sports to Health}

The fundamental right to health articulated by the World Health Organization (WHO) remains integral to development today. This right is strongly reflected in the Millennium Development Goals (MDGS), the guiding international development frame work adopted by the United Nations (UN) in 2000, and the human development index used to measure the progress of all nations against universal human development goals. (WHO's) definition of health as it appeared in the preamble of its constitution in 1946. WHO defined health as "a state of complete physical, mental and social well being and not merely the absence of disease or infirmity. The enjoyment of the highest attainable standard of health is one of the fundamental rights of every human being without distinction of race, religion, and political belief, economic or social condition" Healthy human development is a necessary foundation for all development progress. Without healthy populations, the achievement of development objectives will be out of reach. Good health is fundamental to the ability of individuals to realize their full human potential. It is also a crucially important economic asset. Low levels of health impede productively and economic growth, while investment in better health outcomes is generally seen as an investment in economic growth [6].

Well-designed sport programs that educate, support and empower youth can encourage positive behaviour change by enhancing self-perception, imparting self-esteem, and promoting more conscious care and respect among youths for their own bodies. These critical dimensions of properly designed sport programs with Health Education components can help reduce the vulnerability of young people to substance abuse, premature, unprotected, or unwanted sexual activity, and the transmission of infectious disease through these activities. Individual constant engagement in physical training obviously improves their cardiovascular functions. Their respiratory system is better and able to utilize and process oxygen for muscular work. When two individuals, trained and untrained persons exposed to the same amount of muscular work, there is evidence that, trained people will do well than untrained persons. Participating in sporting activities helps the participants to cope with 
work related stress [7]. Benefits accrue to workers and employers as a result of participating in sporting programmes, an increase in work performance and a better ability to cope with work related stress enhances productivity. Sports act as an antidote to several ailments modern workers contend with. physically activity can help reduce health-care costs and increase productivity. Workplace physical activity programs in the United States have been shown to reduce short-term sick leave from 32\%-6\%, reduce health care cost from 55\%-20\%, and increase productivity from $2 \%-52 \%$. In Canada, companies with employee physical activity programs and initiatives have been shown to save 513 US dollars per worker annually through improvements in productivity, absenteeism, turnover and injury [8].

\section{Contribution of Sport in Promoting Peace among Youth}

There are important evidence regarding the role of sport in building, facilitating social, community inclusion and active citizenship. When coupled with additional behaviours, sport-based programs were successful in promoting social skills generalization among children diagnosed with attention deficit/hyperactivity disorder (ADHD). Given that social skills generalization is unlikely to take place without active efforts, evidence suggests that sport offers one tool to be used to promote pro-social behavior. Research also suggests that sport may provide an opportunity for positive peer interaction and healthy competition for and among youth. Recent research suggests that peer relationships are a key part of young people's experiences in sport, and that social acceptance and affiliation are important components in determining the extent to which children and youth enjoy participating in sport. As young people mature, they increasingly rely on peers for information and feedback regarding physical competence; therefore, sport as a context of physical activity, serves as a key site of child and youth development [9].

In the U.S., the National Recreation and Parks Association identified 621 programs and estimated the number of participants in the "social problems industry" to be in the hundreds of thousands annually. Recent research suggests that sport-based programs focused on children and youth in areas of conflict offer a means of both resolution and, in turn, reconciliation. For example, sport can facilitate positive social opportunities in postwar Africa, where violence and child soldiering have severely restricted or foreclosed the health and welfare of children and youth. Similarly, the success of Open Fun Football Schools in reintegrating ethnic communities in the post-war Balkans, although they caution that "football is something like frontline farmland: fertile, but likely to be mined." When war leads to limited avenues for social and personal development, the importance of physical activity for children and youth may be thought to increase, and participation opportunities become paramount, in the contributions such opportunities afford to children impacted by conflict. These results suggest that, if sport-focused projects are locally grounded, carefully thought out, and professionally managed, they can make a modest contribution to conflict resolution and peaceful coexistence in regions of violence [10].

In fact, in data collected in this survey, the role that sport plays in promoting and developing moral character was considered to be an essential component of the very definition of sport for children and youth, although not surprisingly, these ideas of the positive impact of sports on the development of character tend to come from those coaches, parents, volunteers and participants who are actively involved in children's and youth sport. This "character logic" is often used to encourage and defend children's participation in sport; it is also used to justify the funding of sport programs, the building of facilities and the sponsorship of events. Research has demonstrated that character in children and youth can be enhanced in sport and physical education settings "when fair play, sportsmanship and moral development information is systematically and consistently taught." In other words, given that sport is a powerful social experience in the lives of children and youth, positive character development may occur under the right circumstances.

Sporting events tend to bring different people with different cultures and works of life together. Mere contact with sporting events has a contagious fascination even among the most improbable participants and spectators. That a richly diverse group of spectators-doctors, lawyers, merchants, and women become an ordinary devoted gathering with nothing in common, except sport [11].

\section{Historical Perspective of Boko Haram in Nigeria}

Ustaz Mohammed Yusuf formed Boko Haram in 2002 in Maiduguri. He established a religion complex 'that include a mosque and anIslamic school called Almagiri School. Many poor families from across Nigeria and from neighbouring countries enrolled their children in the school, which also served as a recruiting center for Jihadis to fight the Nigerian state. In 2004 it moved to Kanamma, Yobe State, where it set up a base called "Afghanistan", to attack nearby police outposts, killing police officers. Yusuf is hostile to democracy and the secular education system, vowing that "this war that is yet to start would continue for long" if the political and educational system was not changed [12]. In Bauchi the group was reported as refusing to mix with the local people but preferred living and attacking from the forest call sambiza forest in Borno north east part of Nigeria. The group includes members who came from neighboring Chad and speak only in Arabic.

The Yusufiyya Movement, better known as Boko Haram, came to prominence in Borno State when it helped to bring Governor AH Modu Sherifff to power in 2003 and 
the current troubles began when it fell out with him, chairman of the Peoples' Democratic Party (PDP) in the state Alhaji Baba I, Basharu said in Abuja when he spoke at Media Trust corporate head office when he led a 10member delegation on a visit.

The late Boko Haram leader Mohammed Yusuf was the very man who led a "Taliban" uprising in Yobe State early this decade and fled into exile after a violent clash with policemen. Boko Haram helped to bring Governor Ali Modu Sheriff to power in 2003. He said it was Sheriff's deputy, Adamu Dibal and his secretary to the State Government (SSG), Baba Njidda, who negotiated for Yusuf return from Saudi Arabia [13].

Basharu said when Ali Sheriff was working to snatch Borno state from then Governor Mala Kachallah earlier this decade, he entered into a pact with the Yusufiiya Movement with a promise to implement Sharia rule in Borno State. After becoming governor, he said, Sheriff created a Ministry of Religion Affairs and appointed Alhaji Buji Foi, who was Yusuffiya's national secretary, as its first commissioner. Camps lasted for a while until they fell out when Sheriff did riot fulfill his promise to implement sharia rule. At that point, he said, Mohammed Yusuf ordered Fugu to resign from Sheriffs cabinet and most other staff of the Religious Affairs Ministry brought by Fugu lefts as well. He said subsequently, the Yusufiyya began working to achieve shari'a rule through preaching. At one point, he said, there was a major clash between them and the police at Maidokiri near the GRA in Maiduguri, and some of their members were killed. He said when the Yusufiyya members mounted a procession to the cemetery to bury their dead members, another clash took place with the police. The police accused some of them of riding their motorbikes without crash helmets and in the ensuring clash, 19 people died, Basharu said. According to him, Mohammed Yusuf then went to many security agencies offices demanding for justice for the two episodes, after which his supporters attacked prisons and police stations. This led to events of July 2009 in which Yusuf and other sect leaders were captured and killed, and the sect members dispersed, only to regroup again in the last two years. Asked at what point the Borno PDF took over Boko Haram, Basharu said, "At no point did we take over Boko Haram". Denying that the serial killing of ANPP leaders in the state indicated a PDP connection, he said, "Boko Haram's grudge was against Ali Sheriff. They were against Sheriff, his government, his party and his people, including the bulamas, as well as warders and policemen who they said killed their leaders." Asked about Senator Mohammed All Ndume, who was charged to court in February 2012 for allegedly abetting the insurgents, the Borno PDF chairman said, "Ndume was an ANPP member. He only came into PDP just before the election; when he realized that Sheriff would not give him a fair shot at the guber ticket". He however added that "Ndume is a credible person and we do not believe the allegations made against him. This is a plot by the ANPP and the state government against Ndume because of his rising profile as the biggest political force in southern Borno State." [14]

\section{Boko Haram Activities in Nigeria}

"Hence we cannot tackle the problem of insecurity in Nigeria today, without studying the past sectarians violence of Mohammed Marwa (Alias) Maitatsine. Activities that occurred in 1980, 1982, 1984, 1985, 1988 and 1990 because they are much relevance to the present, and also the future.

a. Mohammed Marwa (Alias) Maitatsine

b. Mohammed Yusuf (Alias) Boko Haram

A brief history of Mohammed Marwa (Alias) Maitatsine. He was originally from Marwa in Northern Cameroon. After his Islamic education he moved to Kano Nigeria in about 1945, he became known for his controversial preaching's on the Qur'an. Maitatsine claimed to be a and saw hijnsetf as a Jmujaddid) in the image of Sheik Usman Dan fodio. Although he is a Qur'anic scholar, but he seemingly reject the hadith and the Sunna regarding the teaching of any other book apart from the Qur'an as paganism. Maitatsine spoke against the use of Radio, Watches, Bicycles, Cars, and the possessions of making more money than necessary. In 1979, he even rejected the prophet hood of Prophet Mohammad, and portrayed himself as one. The British colonial authorities sent him into exile, but he later returned to Nigeria shortly after independence. He went back to Kano and in 1972 he had a notable and increased mass followers of the (Yantatsine) in 1975 he was again arrested by the Nigerian Police for slanders and public abuse of political authorities. But from that period he began to gain acceptance from religion authorities, especially after making Hajj, the Muslim pilgrimage to Mecca. As his followers increases in the 1970s, so did the number of confrontation between his adherents and the police also increased. His preaching attracted largely followers of unemployed youth and migrants and those who felt that mainstream Muslims. Teachers were not doing enough for their communities, since 1980 there had been several outbreaks of sectarian's violence resulting to thousands of deaths, injuries, and arrest, mostly attributable to sectarian's tension and also to some fringe quasi-Islamic groups [15].

The most dramatic eruption in a series of religious disturbance by the Maitatsine movement was, the elevenday emergence in Kano late December 1980, led by Mohammed Marwa (Alias) Maitatsine. Followers of this heretical Muslim sect of perhaps 3,000 persons opposed secular authority, were willing to use violence if necessary, and demand absolute obedience to Mohammad Marwa. The Army suppressed the Kano riots after the Police failed to restore order. More than 4,000 death resulted, including that of Marwa and 1,000 arrests, including 224 foreigners. More riots by Maitatsine followers broke out in Maiduguri in late October 1982 and spread to Kaduna, were 39 sect members killed by vigilantes the official death toll was 188 civilians and 18 Police 635 arrested, but the commission of enquiry afterward concluded that death probably exceeded 500 . Nevertheless in February 1984 members of the proscribe Maitatsine sect struck again this time in northest Yola the capital of Gongola state. The Army was again obliged to intervene. Going by the history of Mohammed Marwa of Maitatsine and Mohammad Yusuf of Boko Haram are 
similar in ideology, otherwise one can easily' be convince, that it was the spillover of the Maitatsine followers that have now form Boko Haram.

Some will say they are religious group fighting against religion, some will like to say they are group fighting against western education, well as a security men and women I don't believe there is anything like (Boko Haram), this people are just using that name to make a undercover to their act, this people are political thugs organized and used by some of our political leaders to cause problem to the government on selfish reason. Some of our political leaders in northern part of the country to gain their political office, this people where promised different kind of promises after which they were abandon without fulfilling the promises to them so they feel the only way to make themselves known to the government is by mass killing and terrorism act given themselves a name suitable to them (Boko Haram meaning the knowledge of book is deceitful and should be forbidding [16]).

\subsection{What is their Method of Operation}

"As people always said that no security is $100 \%$ sure, there is a notion and general believe that these Boko Haram insurgence had their informants even among the nations security and as such the strike using deadlier equipment like bomb hit their target and quickly goes into their hidings even among their tribe who will never exposed them for fear of attacks.

\subsection{Statement of Problem}

Over the years, researchers had observed with keen interest the devastating effects of civil disobedience in various part of the country Nigeria. wars, cold wars, tribal conflicts, ethnics disputes, religious and politically motivated riots and youth unrest such as Odua Peoples' Congress (OPC) disagreement in the south western part of Nigeria, The Jos land dispute, Muslim and Christians misunderstanding, in the North central, Boko Haram menace in the Northeast, Niger Delta Militancy in the Southeast, the cold war and attendant social and political unrest has overshadowed many of the remarkable advances in science and technology in Nigeria and this has really threatened the unity and security of the Nation.

The recent destruction of properties, killings and kidnapping acts perpetrated by the militants has created an emergency situation in most part of the country. The Niger delta militant group always had a faceoff with the military forces which paralyses social and economic activities of the affected states in Nigeria.

The Odua People Congress (OPC) disagreement, Jos ethnic clash, Christians and Muslims misunderstanding in the Northern hemisphere of the nation, Boko Haram bombing menace and the Niger Delta militancy and cult activities which create tension, loss of life, social and political unrest, thus threatening the peace, unity, development and security of the nation. Hatred and violence has enveloped the country which has grounded economic development and emancipation of the nation. Since sports is seen as a unifying force coupled with its multi-cultural values, it tends to bring together people irrespective of tribe, religion, ethnic, race, colour and language difference in the face of national and international sports competitions. The focus of this paper therefore was to ascertain whether the multi-cultural potency of sports, physical education and recreational values will have any impact in promoting healthy living and peace among the youths in Nigeria [17].

\subsection{Focus of the Study}

The main focus of this study was to examine the impact of multi-cultural values of sports, physical education and the potency of recreational sports values on the promotion of peace and healthy living among the youths who are more prone to violence in the country most especially at this period of total insecurity in Nigeria.

The findings of this study therefore will be useful in the improvement, setting of standards and encouragement of debate on policy formulation that could lead to changes in public orientation about health and important of peace through sports.

i. It will serve as a tool for promoting peace and to bring people together for the growth of the Nation.

ii. The findings in essence will be beneficial in the area of motivating directing and teaching the youth on sports ethics that will in turn help in curbing youth unrest in Nigeria.

iii. It may be beneficial to societal practice, reform of mankind in redirecting the minds of the youth in Nigeria from militancy approach to resolving crises.

iv. It will help society to ascertain the life of serving, scarifying, and living for the sake of one single reciprocal partner and the fundamental principle of the orderly existence of the universe.

The following research questions were raised to guide the study:

i. Will sports bring about peaceful ties among the youth in Nigeria?

ii. Will sports serves as a means of bridging social and ethnic divides among the youth in Nigeria?

iii. Will sports penetrate the multi- culture, religion, gender, political break through and suppressed the menace of youth militancy in Nigeria e.g. the Boko Haram menace? 


\subsection{Research Hypotheses}

$\mathbf{H}_{\mathbf{0 1}}$ : There will be no significant impact of multicultural values of Sports, physical Education and Recreational values on peace and healthy living among the youths, in Nigeria.

$\mathbf{H}_{\mathbf{0} 2}$ : There will be no significant relationship between sports and social ethnics divides in Nigeria.

\subsection{Methodology}

The study adopted the descriptive survey design. The study focused was Lagos State. While the study adopted the descriptive research design, the participants consisted of 200 sports administrators, coaches, athletes and spectators randomly selected from 5 public sports centres and 5 private sports centres in Lagos State. The instrument used for data collection was questionnaire while the data collected were analyzed using chi-square statistics and simple percentages to test for all the pre stated hypotheses

\subsection{Data Presentation and Results}

$\mathbf{H}_{\mathbf{0 1}}$ : There will be no significant impact of multicultural values of sports, physical education and recreational values on peace and Healthy living promotions among the youth in Nigeria.

\section{Table 1. Multi-Cultural Values of Sports, Physical Education and Recreational Values on Peace and Healthy Living}

\begin{tabular}{llllll}
\hline R & DF & a & Cal & Cri & $\begin{array}{l}\text { Decisi } \\
\text { on }\end{array}$ \\
\hline 10 & 9 & 0.05 & 198.9 & 16.92 & $\begin{array}{l}\text { Reject } \\
\text { Ho }\end{array}$ \\
\hline
\end{tabular}

$\mathrm{X}^{2}$ calculated or cal $=198.9$

$\mathrm{X}^{2} \mathrm{t}$ abulated or cri $=16.92$

Degree of freedom $=(r-1)=10-1=9$

Level of significant or @ $=0.05$

From the result above it could be deduce that at 0.05 level of significant and 9 degree of freedom chisquare calculated ( $\mathrm{X}^{2}$ calculated) is 198.9 while chisquare tabulated ( $\mathrm{X}^{2}$ tabulated) is 16.92. Based on this result the null hypothesis which stated that there will be no significant impact of multicultural values of sports, physical education and recreational values on peace and healthy living promotion among the youth in Nigeria was rejected. Therefore, it was concluded that there was significant impact of multicultural values of sports, physical education and recreational values on peace and healthy living promotion among the youth in Nigeria if properly manage.
$\mathbf{H}_{\mathbf{0} 2}$ : There will be no any significant relationship between sports, social and ethnic divides in Nigeria.

Table 2. Sports, Social and Ethnic Divides in Nigeria

\begin{tabular}{llllll}
\hline $\mathbf{R}$ & DF & (1) & Cal & Cri & Decision \\
\hline 10 & 9 & 0.05 & 212.56 & 16.92 & $\begin{array}{l}\text { Reject } \\
\text { Ho }\end{array}$ \\
\hline
\end{tabular}

$\mathrm{X}^{2}$ calculated or cal $=212.56$

$\mathrm{X}^{2 \mathrm{t}}$ abulated or cri $=16.92$

Degree of freedom $=(r-1)=10-1=9$

Level of significant or @ $=0.05$

From the result above it could be inferred that at 0.05 level of significant and 9 degree of freedom chisquare calculated $\left(\mathrm{X}^{2}\right.$ calculated is 212.56 while chisquare tabulated ( $\mathrm{X}^{2}$ tabulated) is 16.92 . Based on this result the null hypothesis which states that, "there will be no any significant relationship between sports, social and ethnic divides" was rejected. Therefore, it was concluded that there was relationship between sports, social and ethnic divides in Nigeria.

\subsection{Findings}

However, findings through literature review have shown the following impact of sports, physical education and recreational values on the individuals as well as the community or Nations in general if properly managed:

i. It promotes physical fitness which is associated with development of motor skills, emotional health and acquisition of basic need of safety

ii. It prevents delinquency especially among the teeming youths of any Nation

iii. It creates an outlet to suppress negative feelings.

iv. It helps in personality development among the youth who really love sports

v. Athletes are more stable emotionally, socially and psychologically than non athletes

vi. It Create an avenue for individuals to adjust to situations easily

vii. It Develop the spirit of good sportsmanship, which serves as a carryover values to other overtures by individuals.

\subsection{Recommendation}

Based on the findings, of this study the following conclusion and recommendation are made by the researchers, that;

i. Adequate sporting facilities and equipments 
should be provided in schools and public recreational centers at all time so as to keep the energetic youth busy always.

ii. More public sports centers need to be build or provided to make sporting activities more available, accessible and affordable to all the Nigerian youth.

iii. Government should encourage more competitive sports across culture, religion, gender and political divides in Nigeria mostly among the youth.

iv. More sporting institution should be built for sport development in Nigeria.

v. There should be a day devoted for sports where workers and traders should have a holiday every month as a way to encourage them to participate in sports of their choice, and above all

vi. Government should encourage seminar, conference, workshop where related issues on the economics and social values of sports should be discussed mostly among the Nigerian youth.

vii. Sport promotion should be a responsibility of all so as to bring unity and harmony within and across nations.

\section{Conclusion}

Most people are unaware of these diseases until a point where they cause major complications including death. Active play and sports is the least expensive and most effective preventive medicine for combating the increasing worldwide problem of hypokinetic diseases. Sports can play a critical role in preventing infectious diseases, slowing the spread of chronic diseases, reducing their social and economic burden, and saving lives. Sport and development are natural and complementary process that can enable government and their partners to build a better world. Although, sport alone cannot resolve complex social and economic challenges, it can serve as an educational platform, a mobilization process, a way to strengthen individuals and communities, and a source of joy, inspiration and hope.

Sports and recreational participation have been identified as a way of engendering physical fitness, healthy lifestyle, well and longevity. Thus in most cases exercise is often regarded as medicine. When one ponders what would have happen to Nigeria without sports and recreational activities, what will really come to mind is a state of anarchy and rancor. Imagine what the youth of the entire globe will be without Football Leagues such as: The English Premier Leagues (EPL), Spanish League (Laliga), German Bundesliga, Italian Seria A, French League 1, Canadian Soccer League among others.
Youths should engaged themselves more in recreational activities to curb substance abuse, cultism, killings, and any act of hooliganism, because an idle mind is a devil's workshop.

\section{References}

[1]Awoyinfa, J. O. Modern Trend in Sports Administration and Management, 1st Edition RCC \& Publisher, Lagos.

[2]Fasan, C. O. Introduction to Spots Administration., Beulah Publishers Lagos Nigeria.

[3] Awoyinfa, J. O. Modern Trend in Sports Administration and Management, 1st Edition RCC \& Publisher, Lagos.

[4] Turner, C.E. Personal and Community Health London: Mosby Company.

[5] Jatau, A. A. Promoting Health and Fitness Through Physical Exercise. Health and Fitness Journal International 1(1), 1-6.

[6] Charter, E., Literature Reviews on Sport for Development and Peace. Commissioned by Sport for Development and Peace International Working Group (SDP IWG) Secretariat Toronto, Canada.

[7] Frances, S.W, Eleanor, N.W and Linda, K. D. Health Making Life Choices (2nd ed). American West Educational.

[8] Dale, B. H., Wayne, A. P., Focus on Health (6th ed). New York: McGraw Hill.

[9] Weiss, M.R., Stuntz C.P., “A Little Friendly Competition: Peer Relationships and Psychosocial Development in Youth Sports and Physical Activity Contexts." In M.R. Weiss (ed.), Developmental Sport and Exercise Psychology: A Lifespan Perspective (Morgantown, WV: Fitness Information Technology Inc., 2004), 165-196.

[10] Gasser, P., Levinsen A., "Breaking Post-War Ice: Open Fun Football Schools in Bosnia and Herzegovina," Sport in Society 7(3) (2004):457-472.

[11] Hedstrom, R., Gould, D., Research in Youth Sports: Critical Issues Status. White Paper Summaries of the Existing Literature.

[12] Maguire, J., Sport and Globalisation; Key issues, phases, and trends. In A.A. Raney \& J. Bryrant (Ed.), Handbook of Sports and Media (pp. 435-446). London.

[13] Godwin-Kerika, J. K., Sports Administration in Nigeria, International Tennis Academy, Lagos. Sports and games by G.M. Rider G Bell and Sons Ltd. London.

[14] Maguire, J., Sport and Globalisation: Key issues, phases, and trends. In A.A. Raney \& J. Bryrant (Ed.), Handbook of Sports and Media (pp. 435-446). London. 
[15] Galtung, J., Preface, Inc. Roach (Ed), Communication and Culture in war and peace, (pp xi-xii). Newbury Park, CA: Sage Pub.

[16] Mihoces, G., Competitors Remain Friends despite Ruling.USA Today, 8C.

[17] Godwin-Kerika, J. K., Sports Administration in Nigeria, International Tennis Academy, Lagos. Sports and games by G.M. Rider G Bell and Sons Ltd. London. 